\title{
Effects of Long Term Rice-based Cropping Systems on Soil Quality Indicators in Central Plain of Chhattisgarh
}

\author{
Uttam Kumar $^{1 *}$, V.N. Mishra ${ }^{1}$, Nirmal Kumar ${ }^{2}$, C.K. Dotaniya ${ }^{3}$ and Sandeep Mohbe ${ }^{3}$ \\ ${ }^{1}$ Department of Soil Science and Agricultural Chemistry, Indira Gandhi Krishi \\ Vishwavidyalaya, Raipur, 492012, Chhattisgarh, India \\ ${ }^{2}$ ICAR-National Bureau of Soil Survey and Land Use Planning, Nagpur, 440033, \\ Maharashtra, India \\ ${ }^{3}$ ICAR -Indian Institute of Soil Science, Bhopal, 462038, M.P., India \\ *Corresponding author
}

\section{Introduction}

The definition of soil quality encompasses physical, chemical and biological characteristics, and it is related to fertility and soil health. Many indicators are used to describe soil quality, but it is important to take into account sensitivity, required time, and related properties, than can be explained. Soil physical, chemical, and biological attributes (Karlen et al., 2001) have been used historically as proxies to soil quality (Andrews et al., 2002), which is a concept related to intrinsic characteristics of the soil, to its interactions with the ecosystem, and to the type of land use or management. This implies some degree of subjectivity as to individual perceptions of what can be deemed "good quality" (Blanco and Lal, 2008). More recently, the discussion has been centered on the concept of 'soil health', largely defined for soil biological properties (Doran and Jones, 1996). Both concepts are focused on assessing soil functions in the landscape, but there is no explicit reference state to be used in a soil quality or health framework. Soil quality indicators are normally chosen according to the research focus. The dataset of indicators may be constructed according to expert opinion (Sanchez-Navarro et al., 2015), based on how often the parameters appear in scientific papers or it may be guided solely on statistical criteria. Certainly, it can also consist of the combination of both strategies (Lima et al., 2013). However, comparing soil quality indicators is not an easy task, since there is neither a consensus as to the appropriate indicators to compose the SQI, nor as to the way that they should be selected to minimize personal subjectivity.

According to USDA, soil quality indicators are classified into four categories that include visual, physical, chemical, and biological indicators. Visual indicators can be obtained through field visits, perception of farmers, and local knowledge. These are identified through observation or photographic 
interpretation, subsoil exposure, erosion, presence of weeds, color, type of coverage, and through comparison between systems operated with the unaudited interim anthropogenic, which gives a clear idea whether the soil quality has been affected positively or negatively.. The physical indicators are related to the organization of the particles and pores, reflecting effects on root growth, speed of plant emergence and water infiltration; they include depth, bulk density, porosity, aggregate stability, texture and compaction. Chemical indicators include $\mathrm{pH}$, salinity, organic matter content, phosphorus availability, cation exchange capacity, nutrient cycling, and the presence of contaminants such as heavy metals, organic compounds, radioactive substances, etc. These indicators determine the presence of soil-plant-related organisms, nutrient availability, water for plants and other organisms, and mobility of contaminants. Finally, biological indicators include measurements of micro- and macroorganisms, their activities or functions. Concentration or population of earthworms, nematodes, termites, ants, as well as microbial biomass, fungi, actinomycetes, or lichens can be used as indicators, because of their role in soil development and conservation; nutrient cycling and specific soil fertility. Due to the variety of soil properties that can act as quality indicators, researchers should identify and select the most suitable ones according to the research goals (Nortcliff, 2002). Keeping these points in mind the present study was conducted objective of this work was to study impact of different rice-based cropping system on soil quality indictors under hot humid eastern plateau of India for further evaluation of soil quality.

The study area (Balod district) is a part of Chhattisgarh state of India, lies between $20^{\circ} 24^{\prime}$ to $21^{\circ} 03^{\prime} \mathrm{N}$ latitude and $80^{\circ} 47^{\prime}$ to $81^{\circ} 31^{\prime}$ E longitude, at an elevation of $324 \mathrm{~m}$ above the mean sea level, which occupies an area of 3527 sq. km. In Balod district survey was carried out and identified two important soil orders i.e. Inceptisols and Vertisols. The prominent cropping sequences identified for detailed study were; rice - wheat (RW), rice chickpea (RC), rice - lathyrus (RL) and rice fallow (RF). Rice crop was sown as an autumn-winter crop (July to November) and subsequent crops i.e. wheat, chickpea and lathyrus were grown as winter-spring crop (November to February). Stratified soil sampling was adopted and $10 \%$ of the total villages in the district were taken into consideration. In each village, based on the cropping system, soil samples were taken from Inceptisols and Vertisols, where the crop rotation was followed since 2000. After the harvest of cropping system for each soil sample, five points $(0-15 \mathrm{~cm})$ were taken into account before compositing. A total 40 samples were collected (20 samples for each cropping system), air dried and sieved under shade. The fine earth $(<2 \mathrm{~mm})$ was analyzed for soil physical, chemical, and biological properties following standard laboratory procedures (Table 1).

\section{Soil physical properties}

The mean values of $\mathrm{BD}$ of soils were 1.40, $1.34,1.36$ and $1.37 \mathrm{Mg} \mathrm{m}^{-3}$ for RW, RC, RL, and RF cropping system, respectively (Table 2). The higher amount of added biomass from leguminous crops (chickpea and lathyrus) made soil loose, porous and less squeezed. Therefore, the lower BD was found under rice-legume cropping system (RC and RL) (Rahman et al., 2007). The mean values of PD of soils were $2.65,2.64,2.63$ and $2.63 \mathrm{Mg}$ $\mathrm{m}^{-3}$ for $\mathrm{RW}, \mathrm{RC}, \mathrm{RL}$, and RF cropping system, respectively (Table 2). The PD of soil only affected by size of the particles, therefore, the PD of soils was found to be no difference among the cropping systems (Alam and Salahin, 2013). The mean values 
of porosity of soils were 47.07, 49.16, 48.11 and 47.92 per cent for RW, RC, RL, and RF, respectively (Table 2). The greater extant of added biomass from leguminous crops made soil porous, increase macro pores, makes the soil more voluminous (Bandyopadhyay et al., 2011). Accordingly, the higher porosity was found under rice- legume cropping system. The mean values of FC of soils were 24.50, 32.45, 27.95, and 26.55 per cent for RW, RC, RL, and RF cropping system, respectively (Table 2). The mean values of WC of soils were $16.00,21.45,18.80$, and 16.20 per cent for RW, RC, RL, and RF cropping system, respectively (Table 2). The FC and WC of soils under RC and RL cropping system was higher than that of soils under RW and RF. Rice-legume cropping system added large amount of biomass in to the soil, which make surface soil loose and porous, thus enhance the capacity of soil to store and retain more moisture (Alam and Salahin 2013; Kumar et al., 2018). The mean values of WHC of soils were 33.95, 50.42, 36.68, and 35.74 per cent for RW, RC, RL, and RF cropping system, respectively (Table $2)$. Rice-legume cropping system (RC) store large extant of carbon in to the soil. By the decomposition of organic matter, polysaccharides, fulvic acid and humic acid are produced, which bind soil particles, increase mean weight diameter, improve water stable aggregates, and consequently increase in WHC of soil (Bama and Somasundaram 2017; Kumar et al., 2018). The mean values of $\mathrm{HC}$ of soils were 0.83 , $0.85,0.90$, and $0.86 \mathrm{~cm} \mathrm{hr}^{-1}$ for RW, RC, RL, and RF cropping systems, respectively (Table 2). Rice-legume cropping system notable for organic carbon build-up in soils, which improves soils aggregation (Cotching et al., 2002), reduces $\mathrm{pH}$ and ESP and enhance the hydraulic conductivity of the soils (Bhattacharyya et al., 2000). The mean values of MWD of soils were 0.70, 0.86, 0.79 , and $0.71 \mathrm{~mm}$ for $\mathrm{RW}, \mathrm{RC}, \mathrm{RL}$, and $\mathrm{RF}$, respectively (Table 2). Rice-legume cropping system (RC and RL) having high root mass density, mean root diameter, root diameter diversity and the percentage of fine roots was all positively linked to the stability of soil aggregates by increasing SOC content. Higher root biomass of leguminous crops helped to accumulation of higher amount of SOC through roots and leaf-fall with increased macro-aggregate formation.

\section{Soil chemical properties}

The mean values of soil $\mathrm{pH}$ were $7.2,6.5,6.7$ and 6.8, for RW, RC, RL, and RF, respectively (Table 2). The soil $\mathrm{pH}$ of soils under RC cropping system was lower than that of soils under RL, RF and RW cropping system. This result has been accredited to the well-known soil acidification effects induced by leguminous crops (Burle et al., 1997). Legume plants reliant on $\mathrm{N}_{2}$ fixation take up more cations than anions, resulting in a net export of protons. The mean values of soil EC were $0.16,0.14,0.12$, and $0.13 \mathrm{dS} \mathrm{m}^{-1}$ for $\mathrm{RW}, \mathrm{RC}, \mathrm{RL}$, and RF cropping system, respectively (Table 2). The EC of soils was found to be no difference among the cropping systems (Table 2). The mean values of soil OC were 4.08, 5.8, 4.9, $4.5 \mathrm{~g} \mathrm{~kg}^{-1}$ for $\mathrm{RW}, \mathrm{RC}$, RL, and RF cropping system, respectively (Table 2). Higher SOC was observed in the rice-legume cropping system (RC and RL) may be attributed to these rotations was considered to have high root biomass, higher carbon sequestration capacity and less carbon release than that of soils under RW and RF cropping system (Mitsch et al., 2010). The mean values of soil CEC were $37.35,46.76,41.53$ and $39.58 \mathrm{cmol}\left(\mathrm{p}^{+}\right)$ $\mathrm{kg}^{-1}$ for $\mathrm{RW}, \mathrm{RC}, \mathrm{RL}$, and $\mathrm{RF}$, respectively (Table 2). Rice-legume cropping system store large extant of carbon content in to soil and high carbon content might be responsible for higher CEC. The mean values of available $\mathrm{N}$ of soils were 220.32, 246.95, 
232.72, and $225.30 \mathrm{~kg} \mathrm{ha}^{-1}$ for RW, RC, RL, and RF, respectively (Table 2). Legume is a natural mini-nitrogen manufacturing factory in the field. Legumes playing a pivotal role especially in $\mathrm{N}$ supply to the cereals by symbiotic association between legume roots and rhizobium bacteria. As a result, ricelegume cropping system (RC and $\mathrm{RL}$ ) store more $\mathrm{N}$ rather than RW and RF (Kumar et al., 2018). The mean values of available $P$ of soils were $15.5,19.20,17.6$, and $15.90 \mathrm{~kg} \mathrm{ha}^{-1}$ for $\mathrm{RW}, \mathrm{RC}, \mathrm{RL}$, and RF, respectively (Table 2). A greater $\mathrm{P}$ availability was observed under $\mathrm{RC}$ cropping system presumably due to the lower $\mathrm{pH}$. Crop rotations, especially those with legumes, can increase root colonization by mycorrhizae. Mycorrhizal associations have the greatest impact on increasing $\mathrm{P}$ availability for crops by colonizing root (Newton et al., 2011). The mean values of available $\mathrm{K}$ of soils were $355.78,439.90$, 391.40 , and $371.80 \mathrm{~kg} \mathrm{ha}^{-1}$ for RW, RC, RL, and RF cropping system, respectively (Table 2). The available $\mathrm{K}$ of soils under RW cropping system was lower than that of soils under RC and RL. The mean values of available $S$ of soils were $13.65,17.00,15.15$, and $13.65 \mathrm{~kg} \mathrm{ha}^{-1}$ for RW, RC, RL, and RF, respectively (Table 2). The available $S$ of soils under RW cropping system was lower than that of soils under RC and RL. Similarly, the available $\mathrm{S}$ of soils under RC cropping system was higher than that of soils under RL and RF.

\section{Soil biological properties}

The mean values of soil MBC were 201.98, 234.38, 193.21, and $217.14 \mathrm{ppm}$ for RW, $\mathrm{RC}, \mathrm{RL}$, and RF, respectively (Table 2). The mean values of soil MBN were 771.53, 830.76, 787.08, $783.48 \mathrm{ppm}$ for RW, RC, $\mathrm{RL}$, and RF, respectively (Table 2). Soils under rice-legume crop rotations with a high input and diversity of organic materials are reported to contain higher concentrations of microbial biomass and enzymes as compared with RW and RF cropping systems (Moore $e t$ al., 2000; Kumar et al., 2018). The mean values of soil PMC were 406.29, 429.08, 405.85, and $410.82 \mathrm{ppm}$ for RW, RC, RL, and RF, respectively (Table 2). The mean values of soil PMN were 158.11, 202.78, 164.40, $179.04 \mathrm{ppm}$ for RW, RC, RL, and $\mathrm{RF}$, respectively (Table 2). Retention of crop residue on or near the soil surface has been shown to reduce residue carbon loss and increase SOC over time (Lal 2004). High SOC content, biomass production, microbial activity and lower $\mathrm{C}$ : $\mathrm{N}$ ratio might be responsible for higher carbon and nitrogen mineralization under rice-legume cropping system (Justin et al., 2015). Carpenter-Boggs et al., (2000) reported that crop rotations differing in crop components could have large effects on PMN and $\mathrm{N}$ availability by altering the quantity and quality of residue input. The mean values of acid phosphatase activity of soil were 78.37, 92.00, 90.75, and $83.37 \mu \mathrm{g}$ p-nitrophenol g ${ }^{-1} 24 \mathrm{hr}^{-1}$ for RW, RC, RL, and RF, respectively (Table 2). The mean values of alkali phosphatase activity of soil were $259.55,308.60,308.41$, and $274.17 \mu \mathrm{g}$ p-nitrophenol $\mathrm{g}^{-1} 24 \mathrm{hr}^{-1}$ for RW, RC, RL, and RF, respectively (Table 2). Rice-legume cropping system responsible for high SOC content, biomass production, microbial population and activity, consequently enhance mycorrhizae association. The rhizosphere is directly influenced by root and mycorrhizae secretions of phosphatase enzyme, and sustains dense populations of root-associated and free-living microorganisms. Therefore, soil under rice-legume cropping system contains large quantities of intracellular and extracellular phosphatases. The mean values of urease activity of soil were The 20.66, 31.41, 25.57, and $24.02 \mu \mathrm{g} \mathrm{NH} \mathrm{NH} \mathrm{g}^{-1} 24 \mathrm{hr}^{-1}$ for $\mathrm{RW}, \mathrm{RC}, \mathrm{RL}$, and $\mathrm{RF}$, respectively (Table 2). 
Table.1 Analytical method adopted for soil physical, chemical, and biological properties

\begin{tabular}{|c|c|}
\hline Parameters & Reference to method of analysis \\
\hline Soil texture & tional pipette method (Piper, 1950) \\
\hline Bulk density (BD) & d No. 39, USDA Hand book No. 60 (Richards, 1954) \\
\hline Particle density (PD) & d No. 39, USDA Hand book No. 60 (Richards, 1954) \\
\hline Porosity & culating BD and PD. \\
\hline Water holding capacity (WHC) & Keen raczkowski box method (Piper, 1950) \\
\hline $\begin{array}{l}\text { Soil moisture retention (SMR) at } \\
-33 \mathrm{kpa}(\mathrm{FC}) \text { and }-1500 \mathrm{kpa}(\mathrm{WP})\end{array}$ & $\begin{array}{l}\text { Using pressure plate membrane apparatus as described by } \\
\text { Kumar et al. (2018a) }\end{array}$ \\
\hline Hydraulic conductivity & Constant head method (Klute and Dirksen, 1986). \\
\hline $\begin{array}{l}\text { Aggregate stability } \\
\text { (Mean weight diameter) }\end{array}$ & Yoder's Modified weight sieving method (Yoder, 1936) \\
\hline pH & $\begin{array}{l}\text { pH Meter method No. 21(b), USDA Hand book No. } 60 \\
\text { (Richards, 1954) }\end{array}$ \\
\hline Electrical conductivity (EC) & $\begin{array}{l}\text { EC Meter (in soil suspension) method No. } 04 \text { (b), USDA } \\
\text { Hand book No. } 60 \text { (Richards, 1954) }\end{array}$ \\
\hline Soil organic carbon (SOC) & Walklay and Black’s wet digestion method (1934) \\
\hline Cation exchange capacity (CEC) & $\begin{array}{l}\text { Method No. 19, USDA Hand book No. } 60 \text { (Richards, } \\
\text { 1954) }\end{array}$ \\
\hline Available N & Alkaline $\mathrm{KMnO}_{4}$ method (Subbiah and Asija, 1956) \\
\hline Available $\mathbf{P}$ & Olsen's method as described by Kumar et al. (2018a) \\
\hline Available K & $\begin{array}{l}\text { Neutral normal ammonium acetate method with flame } \\
\text { photometer (Jackson, 1950). }\end{array}$ \\
\hline Available $\mathbf{S}$ & $\begin{array}{l}\text { Turbidimetric method as described by Kumar et al. } \\
\text { (2018a) }\end{array}$ \\
\hline Microbial biomass $\mathrm{C}$ and $\mathrm{N}$ & Jenkinson and Powelson (1976) \\
\hline Potentially mineralized $\mathrm{C}$ and $\mathrm{N}$ & Anderson (1982) \\
\hline Dehydrogenases activity & Klein et. al. (1971) \\
\hline $\begin{array}{l}\text { Acid and alkaline } \\
\text { phosphatase activity }\end{array}$ & Tabatabi and Bremner (1969) using borate buffer $\mathrm{pH} 9.4$ \\
\hline Urease activity & Pancholy and Rice (1973) \\
\hline
\end{tabular}


Table.2 Descriptive statistics of soil properties among different cropping system

\begin{tabular}{|c|c|c|c|c|c|c|c|c|c|c|c|c|}
\hline \multirow[t]{2}{*}{ Soil Property } & \multicolumn{3}{|c|}{ Rice - Wheat } & \multicolumn{3}{|c|}{ Rice - Chickpea } & \multicolumn{3}{|c|}{ Rice - Lathyrus } & \multicolumn{3}{|c|}{ Rice - Fallow } \\
\hline & Mean & Min. & Max. & Mean & Min. & Max. & Mean & Min. & Max. & Mean & Min. & Max. \\
\hline $\mathrm{BD}\left(\mathrm{Mg} \mathrm{m}^{-3}\right)$ & 1.40 & 1.29 & 1.49 & 1.34 & 1.27 & 1.44 & 1.36 & 1.29 & 1.44 & 1.37 & 1.29 & 1.47 \\
\hline PD $\left(\mathrm{Mg} \mathrm{m}^{-3}\right)$ & 2.65 & 2.58 & 2.74 & 2.64 & 2.59 & 2.69 & 2.63 & 2.57 & 2.71 & 2.63 & 2.52 & 2.74 \\
\hline Porosity (\%) & 47.07 & 42.86 & 50.57 & 49.16 & 46.21 & 51.71 & 48.11 & 45.17 & 52.22 & 47.92 & 44.44 & 51.29 \\
\hline SMR \% (-33 kpa) & 24.50 & 16.50 & 32.50 & 32.45 & 26.70 & 38.20 & 27.95 & 21.10 & 34.80 & 26.55 & 21.50 & 31.60 \\
\hline SMR \% (-1500 kpa) & 16.00 & 10.40 & 21.60 & 21.45 & 15.10 & 27.80 & 18.80 & 12.50 & 25.10 & 16.20 & 10.80 & 21.60 \\
\hline WHC (\%) & 33.95 & 18.48 & 43.43 & 50.42 & 42.52 & 58.33 & 36.68 & 20.42 & 52.95 & 35.74 & 14.65 & 56.84 \\
\hline HC $\left(\mathrm{cm} \mathrm{hr} .^{-1}\right)$ & 0.83 & 0.68 & 1.07 & 0.85 & 0.67 & 0.96 & 0.90 & 0.71 & 1.06 & 0.86 & 0.66 & 1.10 \\
\hline MWD (mm) & 0.70 & 0.58 & 0.82 & 0.86 & 0.76 & 0.98 & 0.79 & 0.64 & 0.99 & 0.71 & 0.60 & 0.85 \\
\hline pH & 7.2 & 6.8 & 7.6 & 6.5 & 5.2 & 7.5 & 6.7 & 5.2 & 7.9 & 6.8 & 5.40 & 8.2 \\
\hline EC & 0.16 & 0.04 & 0.32 & 0.14 & 0.08 & 0.23 & 0.12 & 0.03 & 0.26 & 0.13 & 0.02 & 0.28 \\
\hline $\mathrm{OC}\left(\mathrm{g} \mathrm{kg}^{-1}\right)$ & 4.08 & 2.60 & 6.1 & 5.8 & 4.7 & 6.7 & 4.90 & 3.4 & 6.4 & 4.5 & 2.6 & 6.4 \\
\hline CEC $\left[\mathrm{cmol}\left(\mathrm{p}^{+}\right) \mathrm{kg}^{-1}\right]$ & 37.35 & 23.24 & 51.47 & 46.76 & 34.28 & 59.24 & 41.53 & 21.51 & 61.56 & 39.58 & 19.68 & 59.48 \\
\hline Av. N $\left(\mathrm{kg} \mathrm{ha}^{-1}\right)$ & 220.32 & 177 & 251 & 246.95 & 199 & 275 & 232.72 & 164 & 261 & 225.38 & 186 & 258 \\
\hline Av. P (kg ha $\left.{ }^{-1}\right)$ & 15.5 & 9.2 & 21.8 & 19.20 & 14.50 & 23.90 & 176 & 10.40 & 24.80 & 15.9 & 8.7 & 23.10 \\
\hline Av. K $\left(\mathrm{kg} \mathrm{ha}^{-1}\right)$ & 355.78 & 187 & 459 & 439.90 & 387 & 501 & 391.40 & 318 & 475 & 371.80 & 267 & 138 \\
\hline Av. S $\left(\mathrm{kg} \mathrm{ha}^{-1}\right)$ & 13.65 & 7.10 & 20.20 & 17.00 & 12.70 & 21.30 & 15.15 & 10.40 & 19.90 & 13.65 & 7.10 & 20.20 \\
\hline MBC (ppm) & 201.98 & 149.59 & 254.38 & 234.38 & 197.49 & 271.12 & 193.21 & 128.48 & 257.94 & 217.14 & 164.35 & 269.94 \\
\hline MBN (ppm) & 771.53 & 645.62 & 897.45 & 830.76 & 778.74 & 882.78 & 787.08 & 678.57 & 95.59 & 783.48 & 668.54 & 901.42 \\
\hline PMC (ppm) & 406.29 & 326.35 & 486.24 & 429.08 & 359.58 & 498.59 & 405.85 & 304.35 & 507.35 & 410.82 & 348.84 & 472.81 \\
\hline PMN (ppm) & 158.11 & 107.75 & 208.48 & 202.78 & 159.78 & 245.79 & 164.40 & 129.84 & 198.96 & 179.04 & 115.74 & 242.35 \\
\hline $\begin{array}{l}\text { Acid phosphatase activity } \\
\left(\mu \mathrm{g} \text { p-nitrophenol } \mathrm{g}^{-1} 24 \mathrm{hr}^{-1}\right)\end{array}$ & 78.37 & 62.35 & 94.39 & 92.00 & 85.35 & 98.65 & 90.75 & 62.96 & 118.54 & 83.37 & 62.35 & 104.39 \\
\hline $\begin{array}{l}\text { Alkali phosphatase activity } \\
\left(\mu \mathrm{g} \text { p-nitrophenol } \mathrm{g}^{-1} 24 \mathrm{hr}^{-1} \text { ) }\right.\end{array}$ & 259.55 & 208.24 & 310.86 & 308.60 & 259.86 & 357.34 & 308.41 & 248.24 & 368.59 & 274.17 & 202.35 & 345.61 \\
\hline $\begin{array}{l}\text { Urease activity } \\
\left(\mu \mathrm{g} \mathrm{NH}-\mathrm{Ng}^{-1} 24 \mathrm{hr}^{-1}\right)\end{array}$ & 20.66 & 10.57 & 30.75 & 31.41 & 24.25 & 38.58 & 25.57 & 11.68 & 39.47 & 24.02 & 11.48 & 36.57 \\
\hline $\begin{array}{l}\text { Dehydrogenase activity } \\
\left(\mu \mathrm{g} \text { TPF } \mathrm{g}^{-1} 24 \mathrm{hr}^{-1}\right)\end{array}$ & 29.51 & 15.53 & 43.49 & 40.12 & 31.67 & 48.57 & 35.79 & 21.84 & 49.79 & 32.84 & 16.35 & 49.34 \\
\hline
\end{tabular}


Rice-legume cropping system stimulate microbial activity which build-up OC and microbial biomass in to the soil (Campbell et al., 2000). Higher microbial biomass carbon and nitrogen under rice-legume cropping system attributed to the greater urease activity. The mean values of DHA of soil were $29.51,40.12,35.79,32.84 \mu \mathrm{g}$ TPF $\mathrm{g}^{-1}$ $24 \mathrm{hr}^{-1}$ for RW, RC, RL, and RF, respectively (Table 2). Rice-legume cropping systems were found significantly higher DHA might be due to higher microbial activity which was registered in the present study itself. Dehydrogenases are greatly associated with microbial biomass, which in turn mediates the decomposition of organic materials (Zhang et al., 2010).

From the results it is concluded that soil quality indicators were registered optimum for rice- legume cropping systems ( $\mathrm{RC}$ and $\mathrm{RL})$ than that of $\mathrm{RW}$ and $\mathrm{RF}$ cropping systems. Optimum in terms of lower BD, higher porosity, HC, MWD, FC, WHC, available macro- and micro-nutrient status, and high in soil microbial activities. Therefore, to perform soil functions and to sustain productivity rice-legume cropping system could be more effective.

\section{References}

Alam, M.K. and Salahin, N. 2013.Changes in soil physical properties and crop productivity as influenced by different tillage depths and cropping patterns. Bangladesh Journal of Agricultural Research, 38(2): 289-299.

Anderson, J.P.E. 1982. Soil respiration. In Methods of soil analysis, part 2, $2^{\text {nd }}$ ed. Page, A.L., Miller, R.H. and Keeney, D.R. 837-871. Madison, Wisconsin, American Society of Agronomy and Soil Science Society of America.

Andrews, S.S., Karlen, D.L. and Mitchell, J.P. 2002. A comparison of soil quality indexing methods for vegetable production systems in Northern California. Agriculture, Ecosystems and Environment 90, 25-45.

Bama, K.S. and Somasundaram, E. 2017. Soil quality changes under different fertilization and cropping in a Vertisol of Tamil Nadu. International journal of chemical studies, 5(4): 1961-1968.

Bandyopadhyay, P.K., Saha, S. and Mallick, S. 2011. Comparison of soil physical properties between a permanent fallow and a long-term rice-wheat cropping with inorganic and organic inputs in the humid subtropics of eastern India. Communications in Soil Science and Plant Analysis, 42: 435-449. DOI: 10.1080/00103624.2011.542358.

Blanco, H. and Lal, R. 2008. Principles of soil conservation and management. Dordrecht. Springer, p. 617.

Burle, M.L., Mielniczuk, J. and Focchi, S. 1997. Effect of cropping systems on soil chemical characteristics, with emphasis on soil acidification. Plant and Soil, 190: 309-316.

Campbell, C.A., Zenter, R.P., Selles, F., Biederbeck, V.O., McConkey, B.G. and Blomert, B. 2000. Quantifying shortterm effects of crop rotations on soil organic carbon in southwestern Saskatchewan. Canadian Journal of Soil Science, 80: 193-202.

Carpenter-Boggs, L., Pikul, J.L., Jr., Vigil, M.F. and Riedell, W.E. 2000. Soil nitrogen mineralization influenced by crop rotation and nitrogen fertilization. Soil Science Society of America Journal, 64: 2038-2045.

Cotching, W.E., Cooper, J., Sparrow, L.A., McCorkell, B.E., Rowley, W. and Hawkinds, K. 2002. Effects of agricultural management on Vertisols in Tasmania. Australian Journal of Soil Research, 40: 1267- 1286.

Doran, J.W. and Jones, A.J. (Eds.) 1996. 
Methods for assessing soil quality. Special Publication, vol. 49, Soil Science Society of America, Madison, WI.

Jackson, M.L. 1950. Soil Chemical Analysis. (Indian Edition), Prentice Hall of India Ltd. Delhi.

Jenkinson, D.S. and Powlson, D.S. 1976. The effect of biological treatments on metabolism in soil. A method for measuring soil biomass. Soil Biology and Biochemistry, 8: 209-213.

Justin, K., Dea, O., Jones, C.A., Zabinski, C.A., Miller, P.R. and Keren, I.N. 2015. Legume, cropping intensity, and $\mathrm{N}$ fertilization effects on soil attributes and processes from an eight-year-old semiarid wheat system. Nutrient Cycling in Agro ecosystems, 102: 179-194.

Karlen, D.L., Andrews, S.S. and Doran, J.W. 2001. Soil quality: current concepts and applications. Advances in Agronomy, 74: $1-40$.

Klein, D.A., Loh, T.C. and Goulding, R.L. 1971. A rapid procedure to evaluate dehydrogenases activity of soils low in organic matter. Soil Biology and Biochemistry, 3: 385-387.

Klute, A. 1986. Water retention: laboratory methods. In: Klute, A. (Ed.), Methods of Soil Analysis, second ed. Elsevier, Madison, WI, pp. 635 -662 (pt. 1).

Kumar, U., Mishra, V.N., Kumar, N., 2018. Comparative study of soil quality indicators for rice-based cropping system in Vertisols of central plain of Chhattisgarh. Asian Journal of Soil Science 13(2), 136-147. DOI: 10.15740/HAS/AJSS/13.2/136-147.

Kumar, U., Mishra, V.N., Kumar, N., Rathiya, G.R., 2018a. Methods of Soil Analysis. Kalyani Publishers, Ludhiana, pp. 17-22.

Lal, R. 2014. Soil carbon sequestration impacts on global climate change and food security. Science, 304:1623-1627. doi: 10.1126/science.1097396.

Lima, A.C.R., Brussaard, L., Totola, M.R., Hoogmoed, W.B. and Goede, R.G.M. 2013. A functional evaluation of three indicators sets for assessing soil quality. Applied Soil Ecology, 64: 194- 200.

Mitsch, W.J., Nahlik, A., Wolski, P., Bernal, B., Zhang, L. and Ramberg, L. 2010. Tropical wetlands: seasonal hydrologic pulsing, carbon sequestration, and methane emissions. Wetlands Ecology and Management, 18: 573-586.

Moore, J.M., Susanne, K. and Tabatabai, M.M. 2000. Soil microbial biomass carbon and nitrogen as affected by cropping systems. Biology and Fertility of Soils, 31: 200-210.

Nortcliff, S. 2002. Standardization of soil quality attributes. Agriculture Ecosystem and Environment, 88: 161168.

Pancholy, S.L. and Rice, E.L. 1973. Soil enzymes in relation to old field succession: amylase, cellulose, invertase, dehydrogenase and urease. Soil Science Society of America. Proceedings, 37: 47-50.

Piper, C.S. 1950. Soil and Plant Analysis. Hans Publishers, Mumbai, pp. 368

Rahman, M.N., Rahman, M.M., Islam, M.B., Begum, R.A. and Mondol, A.T.M.A.I. 2007. Effect of tillage practices on soil properties and moisture conservation under Maize -GM-T. Aman cropping sequence. Annual Research Report, Soil Science Division, Bangladesh Agricultural Research Institute, Gazipur.

Richards, L.A. 1954. Diagnosis and improvement of saline-alkali soils. USDA Handbook No. 60, U.S. Department of Agriculture, Will Washington, D.C.

Sanchez-Navarro, A., Gil-Vasquez, J.M., Delgadoiniesta, M.J., Marin- 
Sanleandro, P., Blancobernardeau, A. and Ortiz-Silla, R. 2015. Establishing an index and identification of limiting parameters of characterizing soil quality in Mediterranean ecosystems. Catena, 131: 35-45.

Subbiah, B.V. and Asija, G.L. 1956. A rapid procedure for the determination of available nitrogen in soils. Current Sciences, 25: 259-260.

Tabatabi, M.A. and Bremner, J.M. 1969. Use of p-nitro phenyl phosphate for asses of phosphate activity. Soil Biology and Biochemistry, 1: 301-307.

Yoder, R.E. 1936. A direct method of aggregate analysis of soils and a Study of the physical nature of erosion losses. Agronomy Journal, 28: 337-351.

Zhang, W.J., Wang, X.J., Xu, M.G., Huang, S.M., Liu, H., Peng, C. 2010. Soil organic carbon dynamics under longterm fertilizations in arable land of northern China. Biogeosciences, 7: 409425 .

\section{How to cite this article:}

Uttam Kumar, V.N. Mishra, Nirmal Kumar, C.K. Dotaniya and Sandeep Mohbe. 2019. Effects of Long Term Rice-based Cropping Systems on Soil Quality Indicators in Central Plain of Chhattisgarh- Short Communications. Int.J.Curr.Microbiol.App.Sci. 8(04): 1544-1552. doi: https://doi.org/10.20546/ijcmas.2019.804.179 